\title{
"Deeper Than Even the Grain Goes": Attending to Sound as Pedagogical Practice in Alphonso Lingis's The Murmur of the World
}

Patrick Howard, Cape Breton University

patrick_howard@cbu.ca

\begin{abstract}
This article uses Alphonso Lingis's essay The Murmur of the World as a catalyst for a phenomenological inquiry into the experience of making room for an articulate world; a world that speaks. A great deal has been written about vision as our primary source of insight and understanding. Visual perception dwarfs the other modalities by which we know the world. In The Murmur of the World, Lingis calls us into the realm of background noise where things hum with activity, but are rarely noticed. I propose that the soundscape can be lifted out and re-animated, and so, too, our world, with deeper awareness and innovative listening. Drawing on the work of Jane Bennett and Theodor Adorno, I suggest a creative, pedagogical practice may bring forth for us the community of vital, expressive presences in which we are immersed.
\end{abstract}

\section{Resonating the Noise of Life}

As a child, I was intrigued by the old riddle,

"If a tree falls in the forest, does it make a sound?"

"Of course," I thought. I imagined an ancient spruce crashing to the forest floor in spectacular fashion. "The answer is so obvious; how can this even be a riddle?"

"Yes, but what if there's no one around to hear it," my brother explained, "Does it still make a sound then?"

"Well, the animals would hear it."

"They don't matter; it has to be a person," my brother countered.

"Why?"

"Because animals can't tell you if the tree makes a sound; only people can. And if there's no people, there's no sound!" 
"See? That's philosophy," he added imperiously, "You're too young to get it."

I did not understand the existential dilemma at the heart of the question. But that childhood riddle has returned to me frequently over the years, most often when on walking trails in old growth forests, and I meet an impressively large hemlock or birch on the forest floor. Decaying, disappearing under a thick coat of moss, sprouting saplings, it lays immovable in the cool of shade and dappled light of the towering canopy. It would be many years before I would also come to understand the tacit claim at the heart of the riddle - a claim that the natural world is essentially socially constructed.

Of unknown origin, the puzzle was posed as a thought experiment and came into popular discourse in the mid-nineteenth century. In 1884, Scientific American took up the question from a technical perspective. "Sound is vibration ... recognized as sound only at our nerve centers. The falling of the tree or any other disturbance will produce vibration of the air. If there be no ears to hear, there will be no sound" (Emphasis added, p. 218). According to Scientific American, my brother was right. But for me, the childhood puzzle denied the independent existence of nature. The animals "don't count, it has to be a person." The existence of sound is dependent on "our nerve centers," and human senses that, in this case, cannot only describe or represent the sound the falling tree makes, but constitute it and make it real. Nature becomes an artifact of language and reality; a product of the activity of our imagination. "No people, no sound," means that the tree, the forest, and the dramatic fall to the forest floor have no inherent structures or patterns of their own; they are structured discursively only.

The riddle separates me from the life of the tree; it confuses and unsettles. The fundamental understanding of the world at the heart of the puzzle creates a chasm; an extreme sociological and scientific reductionism that becomes distressingly apparent in characterizing how humans relate to the non-human world. Much later in life, I came to appreciate that the ways we perceive nature are deeply affected by culture. As humans, we are a part of nature and contribute to the way it functions, even on a planetary scale, but that is a long way from asserting that nature is socially constructed or that it does not exist in its own right outside the boundaries of our ability to recognize, name, and describe it.

Outside the human-built, industrial world, Barry Lopez notes, "language is not something man imposes on the land... The very order of the landscape, the ecology of its sounds and thoughts, derives from the mind's intercourse with the landscape" (as cited in Kidner, 2000, p. 357). Lopez points to what I tacitly knew as a child that our relationship with the non-human world is more akin to a dance, an interplay of separateness and interdependence. As language -ing beings in an intelligent body we have tremendous potential to deepen our relationship with a world that also speaks. I have also learned from First Nations peoples of states of being and ways of knowing that represent very different ontological orientations. Indigenous peoples have lived for millennia within an animated, vital relationship with a more-than-human world represented by a deeply lived interdependence that is reciprocal and co-constituted (Beeman \& Blenkinsop, 2008). And it is coconstituting the world through speaking and listening to the language of the world, the sounds, utterances, and expressive meanings that preoccupies me these days.

The poet Gary Snyder (1990) posits that the natural world creates texts that can be read. "The stratigraphy of rocks, layers of pollen in a swamp, the outward expanding circles in the trunk of a tree can be seen as texts" (p. 66). David Abram (2010) describes in dramatic fashion how a potentially life-threatening experience with sea lions, “...initiated me into a layer of language much older, and deeper than words. It was a dimension... Wherein the body itself speaks - by the tonality and rhythm of its sounds, by its gestures... A carnal zone of articulations broadly shared across 
species... To a fully embodied animal any movement might be a gesture, and any sound may be a voice, a meaningful utterance of the world" (p. 167)!

A childhood puzzle, the noise created by a falling tree, the ecology of sounds, a language much older than words are all provocatively taken up by Alphonso Lingis (1994) in his essay The Murmur of the World. It is Lingis who best articulates for me the sonic abilities of both the animate and inanimate world and the expressive power to communicate. Lingis describes an articulate environment, but also a receptive, listening landscape. In the human realm, Lingis, perhaps presciently, points to our current uneasiness with information and communication technologies and vexing questions of privacy. "There is always an enemy, a big brother listening in on all our conversations, and that is why we talk quietly behind closed doors" (1994, p. 72). He describes the ubiquity of billboards and screens "upon which messages are written in neon flashes...The roads and paths to the furthest retreats in the country are lined with wires tense with stock exchange pandemonium; beams bounced off satellites in outer space penetrate all the walls" (p. 73).

One murmur to which Lingis (1994) points in his essay is "the noise internal to communication" (p. 92). And in doing so, he attributes an expressive capacity to all sensible phenomena. The "background noise" as it is described by Lingis is, in essence, a language by which things communicate something of themselves to the world. The background noise, or "the noise of life" as Lingis describes it, is:

...the pulse and wobble, the opacity and the timbre of the voice, the noise each of us is in our own particularity... The sonorous elements with which words are formed... the sighs, gasps, waverings, dronings, hissings, sobs, giggles, whimperings, snivelings, screams, snortings, purring, mutterings, and moanings out of which, sometimes, words are formed. (p. 91)

In this sense human speech reflects and radiates the sonic qualities of other beings, the cacophony of other articulations so abundant in the world. We resonate our earthly surroundings. Lingis (1994) points to the capacity of all living things for speech and to the communicative power of objects in this way:

To live is to echo with the vibrancy of things. To be, for material things is to resonate. There is sound in things like there is warmth and cold in things, and things resonate like they irradiate their warmth and cold. The quail and albatross, the crows and the hummingbirds, the coyotes and the seals...the schooling fish and the great whales. The crocodiles infrasonically and praying mantises ultrasonically continue and reverberate the branches, the fluttering of the leaves, the bubbling of the creeks, the hissing of the marsh gases, the whirring of the winds, the shifting of the rocks, the grinding of the earth's plates. (pp. 96-97)

And yet, how do we experience this vibrancy, this resonance, these sounds, this "noise of life" to which Lingis refers? Experientially, it exists in the background, below my day-to-day awareness. Increasingly, we live in a visual world; we perceive the world visually. How do I make room for an articulate world, a world that speaks, for things to resonate? What is that like? Visuocentrism, says O'Callaghan (2007), has shaped our understanding of perception and its role. An inordinate amount has been written about vision as a source of insight into perception. As we are, purportedly, predominately visual beings, visual perception and the attention it receives dwarfs the other modalities by which we know the world. In The Murmur of the World Lingis calls us into the realm of background noise, behind the curtain and into the wings where things hum with 
activity, but are rarely noticed. "We understand that background noise is essential when we understand that reception in the communication system of our bodies is not the passive exposing of a pre-programmed surface of sensibility to outside stimuli, but picking a signal out of the multiplicity of irrelevant and conflicting signals" (1994, p. 45). Lingis contends that the background noise is essential to communication. But in what ways is this so?

\section{Sounds as Individuals Moving Through}

As I sit writing, the house is silent; yet, a warm, heavy and steady rain thrums just perceptibly on the roof, the dog pants rhythmically under the table, car tires whir on the pavement through runnels of rainwater. These sibilant undertones may be considered the 'voice' of silence, the many articulations of the absence of noise. Mendes-Flohr (2012) reminds us silence presupposes the prior experience of sound. I know many people experience the absence of definable sound, or silence, as welcoming and as having a calming effect. Others find the quiet threatening and disquieting. A quiet house begs to be filled with sound, with television, radio, music played through headphones on devices and computers. Mendes-Flohr (2012) re-tells the story of Thomas Carlyle, the Scottish philosopher and newly settled resident of bustling London, who wrote to a friend in 1840, "SILENCE, SILENCE: in a thousand senses I proclaim the indispensable worth of SILENCE, our only safe dwelling place often..." (p. 15). Carlyle's quest for quiet proved fruitless. He tried to quell the clamour of the burgeoning city, the roosters, horses, hawking peddlers, and noisy neighbours by building a soundproof study. While it blocked some sounds, others were more audible. "The silent room is the noisiest in the house," (p. 16) Carlyle's wife observed with wry irony.

In silence, I am immersed in a soundscape available to me in the now. What happens when we abandon visuocentrism to regard sounds not only for what they reveal about the world and about what is visible, but also as entities in their own right? The soughing rise and fall of the dog's breathing, the hum of the refrigerator, the thrumming resonance of rain affords me a threedimensional spatial field, surround-sound in today's parlance. Visually my field is restricted to my computer screen and a narrow peripheral band to my left and right. In my soundscape, I am able to detect change and monitor multiple sources of information. Lingis reminds us of the importance of the "sonorous field" and our ability to perceive a sonic figure; "perception is the active power to focus in on, isolate, segregate, shape a figure, and reduce the rest to indifferentiation" (p. 93). Lingis explains seeing a figure standing out against adjacent objects is not due in large part to the power of our gaze and not solely the mechanism by which an image is flashed on our retinas. In the absence of a background, actively separating a figure, there can be no figure. Psychologists have cleverly designed many demonstrations of just this phenomenon. So, too, then says Lingis, do we need the hum of the field the noise of life to communicate. He points to the sensory deprivation tank experiments of the 1960's developed by a diver wanting to re-create on dry land the silence and euphoria of deep sea diving. "But the technology that eliminates the noise eliminates the communication" (1994, p. 93). In the total absence of the auditory, visual and tactile, the sensory "background noise" "one no longer senses the boundaries between outside and inside, past and present, perception and images, and one soon hallucinates" (Lingis, 1994, p. 93). Sound as this mysterious thing grounds us here in the now.

The rain has stopped, the refrigerator motor has quit temporarily, the dog continues to snooze, and the silence is filled with the sounds I hear created by ordinary things or happenings in 
the environment... my watch beeps the hour, the cell phone on the counter vibrates with an incoming email. I hear by way of hearing the sounds objects make. This would seem to be a rather innocuous statement. Reflecting on the soundscape, the noise of life, being auditorily aware of anything requires being aware of a sound. O'Callaghan asserts that sounds are "events" in and of themselves and are "particular individuals that possess the audible qualities of pitch, timbre and loudness, possibly other inaudible qualities" (2007, p.17). Sounds have lifetimes and have similar and different relations to each other depending on the array of audible qualities they hold. Sound sources, the sleeping dog, the refrigerator count among ordinary things and events, and they stand "in causal relations of making or producing sounds but are not at intervals simply qualified by their sounds (O'Callaghan, 2007, p. 17). Sounds have identity, individuation, and persistent conditions that require us to distinguish them from the properties of the sources that we understand to make or produce the sounds.

Reflecting on the experience of sound lifts the sound out and gives something more solid to what is mysterious and ethereal. It provides sound with a life independent of the object and the happening producing it. The eerie creak of tree trunks, the tremble of aspen leaves, the powerful shush of pine needles as wind plays across high tree tops all have complex and multi layered meanings as sound events in their own right. Like words spoken, language uttered communicates meaning independent of the vocal mechanism producing it; so, too, is meaning created by the background noise or Lingis's "noise of life" for those who are attentive and aware. David Abram (2010) relates a story of meeting a man in the Pacific Northwest who has "schooled himself in the speech of needled evergreens" (p. 171). With the right wind conditions, the man could be blindfolded and driven to any patch of trees along the coastal forests and having spent a few moments beneath a particular tree, he could tell you "by listening just what species of pine or spruce or fir stood above him (whether he stood beneath a Douglas fir, a Sitka spruce, or a Western red cedar). His ears were attuned, he said, to the different dialects of the trees" (2010, p.171). Abram anticipates the reaction to the ludicrous notion of different dialects being attributed to trees since the sound is created not the by the tree but by the event of the wind blowing through the tree. Abram points out that people making this argument "seem not to notice that it is demonstrably the same when they speak. "We talk after all only by shaping the exhaled air that rushed into our lungs a moment earlier. Human speech, too, is really the wind moving through" (Abram, 2010, p. 171).

\section{Cries, Whistles, Hoots: Sound that Lives and Breathes}

Understanding sounds as having identity, a duration, a lifespan, and complex patterns of changes in pitch, timbre, and loudness enriches the listening subject. Such an orientation toward sound facilitates an innovative listening and produces a world whereby the auditory self is part of a sonorous, reciprocal intersubjectivity. The world of objects and events becomes re-animated, in a way, with a vitality. "We are vital materiality and we are surrounded by it," says Jane Bennett (2010), "even if we do not always see it that way" (p. 14). Disrupting our conceptualization of sound, of background noise, of inert objects and happenings to expose a language older than words and sounds, utterances that constitute Lingis's "noise of life" is, in many ways, a pedagogical undertaking.

The Atlantic Canadian poet Brian Bartlett (2001) writes in The Afterlife of Trees: 
And in a table I sanded and finished this week...Four grades of sandpaper drew out alder's "nature," inimitable amoeba shapes, waves, half-moons, paw prints dissolving in mud. What looks more beautiful after death? We sand and sand, but under stain, beyond pottery and books, our fallen hairs trapped in the varnish, something remains like memories of a buck rubbing its horns on bark. Soaked in deeper than even the grain goes: cries, whistles, hoots. (p. 25)

Sounds are like spirits trapped that permeate while moving through and around the visual object. The wood holds the sounds, the expressive power of an animate earth. The table reflects a sonic life-world that is silent, yet compelling, drawing us into an auditory imagination. The pedagogical question is posed, How do we open our imaginations to become perceptually aware of a sentient world, to discern non-human vitality, to hear and to listen for an articulate world in which sound lives and breathes as an entity in its own right?

In The Murmur of the World, Alphonso Lingis challenges the nature of communication; "Communication is an effort to silence, not the other, interlocutor, but the outsider, the barbarian, the prosopopoeia of noise" (1994, p. 71). Lingis's choice of the word barbarian is interesting, and with closer examination, we can recover a sense with which the word was once imbued. Barbarian is from the Greek barbaros meaning foreign, strange, and ignorant; but the earlier root of the word barbar is echoic of the unintelligible speech of foreigners and the sound is related to the Sanskrit barbara which means "to stammer" (Etymology online). "Entering into communication," Lingis says, "means extracting the message from its background noise" (p. 70). It is the irrelevant and ambiguous signals that must be pushed into the background, "the regional accents, mispronunciations, stammerings, coughs, ejaculations, words started then canceled, and ungrammatical formulations and the cacography in the graphics" (p. 70). But, Lingis says, there cannot be communication without the background noise, "the teeming flood of signals emitted by what is particular, perspectival, and distinctive in each thing" (p. 93). What happens when I become aware of a rich, diverse soundscape that surrounds me that grounds human communication in the wildness of life? Salomé Vogelin (2010) illustrates the possibility this way:

Listening in the library draws me into the minutiae of human sounds. Every hum, cough, whisper, every footstep, sneeze, paper turn, rasp, and throat clearing is amplified... In its rising and falling the sounds of the library invite the imagination of a boundary-less mass of human flesh. Hearing in its own rhythm, oozing sighs, and whispers and grasping me in its breath; a fleshly monster... As I look up I know the people are sitting at a distance, heads in books; their purposes firmly rooted in their visual worlds. But in sound they come closer. They become the people of my auditory imagination. They start to breathe down my neck and if I do not stop listening I will only be able to hear them. (p. 12)

And, too, the poet Brian Bartlett (2001) reminds us we can listen as an aesthetic practice. The physical act of sanding the table in its tactility reveals the visual, the grain of the wood, the "inimitable amoeba shapes." But it is the sound, when we listen, that expands and augments the visual. Listening produces, invents, and generates, for "soaked in deeper than even the grain goes: cries, hoots, whistles" (2001, p.25). The sonic thing-ness of the table is revealed as a complex interplay of lived time, space, and body. The vital materiality of the table is its presence, both concrete and formless, perceptible and fleeting, is discernible in the moment through a reciprocal sensory field of exchange. The starting point for any pedagogy inside this type of aesthetic practice is the recognition of human participation in a shared, vital, and articulate world. Human speech is 
rife with the noise of the world; animal and objects radiate a communicative power. This expressiveness can be explored pedagogically whether it be our human chatter or the broad articulation of the world.

\section{The Pedagogy of Playful Re-Animation}

Jane Bennett (2010) turns to Adorno's concept of non-identity and negative dialects to offer a pedagogical practice to open channels to listen for a vital, articulate world. Non-identity is the name Adorno gives to "that which is not subject to knowledge but is instead 'heterogeneous' to all concepts" (2010, p. 14). Adorno describes non-identity as a presence that acts upon us; we knowers are haunted, he says, by a painful sense that something is being forgotten or left out. "This discomfiting sense of the inadequacy of representation remains no matter how refined or analytically precise one's concepts become" (Bennet, 2010, p. 14). Adorno, according to Bennett, put forward his method of negative dialectics to teach us to accentuate this discomforting experience, to give it meaning. Negative dialectics as pedagogical practice allows us to bring forth the community of expressive presences in which we dwell and reminds us, "life always exceeds our knowledge and control" (Bennett, 2010, p. 14). Adorno's project was to provide us a way to keep remembering this and learn to accept it. Only then Adorno thought, could we stop raging against a world that refuses to offer us the "reconcilement" (as cited in Bennett, 2010, p. 14) that we crave.

Adorno's pedagogy includes cognitive as well as creative practices. Cognitively the goal is to become more aware that "conceptualization automatically obscures the inadequacy of its concepts" (Bennett, 2010, p. 14). Bennett calls the conceptualization a "cloaking mechanism" that critical reflection can reveal so "felt presences" or non-identity, expressive presences or vital materialism can be revealed. Lingis, too, makes a similar observation. "To abstract from the noise of the world is to be a rationalist" (1994, p. 80). Conceptualization is a type of hubris as concepts can never provide a clear view by themselves. Adorno says, the "discriminating man" employing his method subjects his conceptualizations to a "second order" reflection and pays close aesthetic attention to the objects "qualitative moments" for these reveal an expressive, animate world largely unavailable to rational conceptualization.

The qualitative moments and aesthetic reflection point to the creative or playful element in Adorno's pedagogy. Adorno addresses the imagination as a means to re-create that which has been lost or distorted through conceptualization. The vital presences of things, their communicative power can be exposed through imagination and creativity which, according to Adorno, may bring a person to the place of playing the fool, engaging in the foolish, the playful. "He must not deny his clownish traits, least of all since they alone can give him hope for what is denied" (Adorno, 1973, p. 14). To overturn the privilege of the conceptual for an attunement, a playful curiosity and wonderment for the expressive potential of trees, waves, sounds, and rocks requires an imaginative capacity to attend to the vital presences of the world around us and a respectful attunement for the presence of one another. To re-animate the world is a pedagogical and ethical project for our time. Lingis (1994) laments:

The community we must want must not want to hear the glossolalia of non-human things - the humming, buzzing, murmuring, crackling and roaring of the world, must not want to hear the stammering, quavering, dronings of one another's voices, and must want its hearing adjusted to hear the mathematics relayed by satellites in outer space. (p. 85) 
Lingis reminds us in his essay that murmurs of the world resonate in our human capacity for language and imagination. Long have these been argued to define our creaturely intelligence. That intelligence is refined, enriched, enhanced, and re-constituted by re-affirming our membership in a world of articulate, animate others- a community of expressive beings.

A tree falls in the forest... the anthropocentric hubris that underlies the childhood thought experiment narcissistically places the human ear, the organ of reception as somehow creating the sound in the first place. In his recent book The Hidden Life of Trees the German forester Peter Wohlleben (2016) opens possibilities through emerging empirical evidence that trees are intelligent, networked entities with highly evolved abilities. Trees emit ultrasonic vibrations detected as a crackling of roots in times of scarcity of water. Scientists from three Swiss institutions listened carefully to the trunks of trees. "They registered a soft murmur... Above all, at night. At this time of day most of the water is stored in the trunk, the leaves take a break... the water is held almost completely immobile... nothing flows" (2016, pp. 58-59). So where are the murmuring noises coming from asks Wohlleben. We do not know the answer, definitively. It is a mystery.

The deep mystery of the forest, the myriad others that live on, in and around the tree that falls are a transformative community; for the fallen tree will become a place of re-birth whose life shifts in and out of time, space, and form. It is an animate other, a life force, an intelligence in its own right capable of its own communication, its own murmur, in a dynamic, intelligent world.

\section{References}

Abram, D. (2010). Becoming animal: An earthly cosmology. New York: Pantheon Books.

Adorno, T. (1973). Negative dialectics. (E.B. Ashton, Trans.). New York, NY: Continuum.

Bartlett, B. (2001). The afterlife of trees. In H. MacDonald \& B. MacLaine (Eds.), Landmarks: An anthology of new Atlantic poetry (25)). Charlottetown, PEI: Acorn Press.

Beeman, C. \& S. Blenkinsop. (2008). Might diversity be ontological: Considering Heidegger, Spinoza, and indigeneity in educative practice. Encounters in Education, 9, 95-107.

Bennett, J. (2010). Vibrant matter: A political ecology of things. Durham: Duke University Press.

Kidner, D. (2000). Fabricating nature: A critique of the social creation of nature. Environmental Ethics, 22, $339-357$.

Lingis, A. (1994). A community of those who have nothing in common. Bloomington: University of Indiana Press.

Mendes- Flohr, P. (2012). Dialogical Silence. In H. Fiska Hagg \& A. Kristianse (Eds.), Attending to Silence: Educators and Philosophers on the Art of Listening (15-22.) Helsinki: Portal Books.

O’Callaghan, C. (2007). Sounds: A philosophical theory. New York: Oxford University Press. 
Online Etymology Dictionary (2018). Barbarian. https://www.etymonline.com/word/barbarian

N.A.(1884). Scientific American. April 5th. p. 218.

Snyder, G. (1990). The practice of the wild. New York: North Point Press.

Wollebhen, P. (2016). The hidden life of trees: How they feel, how they communicate. Vancouver: Greystone Books. 